\title{
Increasing the Ability to Read the Alqur'an through Contextual Approach
}

\author{
Rudi Hartono $^{1, *}$, Yumna Rasyid ${ }^{2}$, Wuryani $^{3}$, Adi Apriadi Adiansha ${ }^{3}$ \\ ${ }^{1}$ Department of Primary Education, State University of Jakarta, Jakarta, Indonesia \\ ${ }^{2}$ Department of Applied Linguistics, State University of Jakarta, Jakarta, Indonesia \\ ${ }^{3}$ Department of faculty of Science Education, State University of Jakarta, Jakarta, Indonesia \\ *Corresponding author: hartonorudi037@gmail.com
}

Received December 04, 2018; Revised January 06, 2019; Accepted January 23, 2019

\begin{abstract}
This study aims to improve the ability to read Al-quran in children in Grade IV SLIPI 15 SDN Morning. This study uses the method of action research model Kemmis and Taggart, which includes four stages, namely (1) planning, (2) action, (3) observation, (4) reflection. By giving an action to the subject under study through the contextual approach as an independent variable and to know the improvement in children's Al-quran reading ability as a dependent variable. The results of the study indicate that there is a process of increasing outcomes in children's Al-quran reading skills through the contextual approach. This can be seen starting from the pre-intervention results up to the second cycle where the social skills possessed by class B students as a whole increased with an average of $49.3 \%$. The results of the pre-intervention mean were $34.7 \%$ and increased up to $84 \%$ in the cycle I.
\end{abstract}

Keywords: the ability to read, the Al-Qur'an, contextual approach, action research

Cite This Article: Rudi Hartono, Yumna Rasyid, Wuryani, and Adi Apriadi Adiansha, "Increasing the Ability to Read the Alqur'an through Contextual Approach.” American Journal of Educational Research, vol. 7, no. 1 (2019): 93-96. doi: 10.12691/education-7-1-14.

\section{Introduction}

To realize an Islamic society, many things are very much needed, including the ability to read and understand Alqur'an, because Alqur' a recommends that people deepen their knowledge in various fields of science. By reading and understanding Alqur'an verses, one can understand the life of the world and the hereafter. In the Alqur' a verse which was first revealed by Allah Almighty,

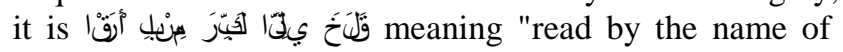
your God who created" [1], then indeed all knowledge is started and gained through reading, because reading is the beginning of understanding knowledge [2,3]. Every Muslim who believes in Alquran has an obligation and responsibility for his holy book. Among the obligations and responsibilities is to study it and teach it. Learning and teaching Alquran is a sacred and noble obligation. The Messenger of Allāh has said "You are the best who learn the Alquran and teach it" [4].

Given the importance of the ability to read the Koran in everyday life [5,6,7], it is necessary to have a good and correct concept of learning to make it easier for children in reading the Qur'an. Alquran reading learning is inseparable from the role of the teacher who is very important in teaching reading Alqur'an. Therefore teachers are expected to be able to support children to be able to read Alquran as expected.
Islam which adversely affects the ability to recite the Alqur'an due to the first difficulty in reading the Qur'an, the long sentence in the Qur'an and the sounds or phonemes of Arabic that do not exist in Indonesian, for example the letter Ghain $(\dot{\xi})$, and students still confused how to read letters or connect the letters of the Qur'an in accordance with the procedure for reading the Qur'an (tajwid). Both students lack involvement in Alquran reading learning. This results in the absence of interaction between students and teachers, where the teacher does not provide opportunities for students to find ways to read the Koran, and the teacher does not fully provide the right contribution or present learning in accordance with the real world of children in the process of reading the Koran, both in letter recognition, letter form and others.

This is evident from the results of class IV at SDN Slipi 15 Pagi, Palmerah District, West Jakarta. The low learning outcomes of Islamic Education are evidenced by the results of daily tests in Semester I which only obtain an average of 65 . The results achieved are very low and do not meet the Minimum Completion Criteria (KKM) which is 72. Islamic Education as the knowledge that students must have as a foundation and provision of life in the world and in the hereafter.

Furthermore, the approach that can improve the ability to read the Qur'an is the Contextual Teaching and Learning (CTL) approach as an alternative problem solving because in solving problems associated with students' real life means students are directly involved in 
the learning process (Nafia, 2017; Ya'cub, 2014) Besides that, the Contextual Teaching and Learning has advantages in seven steps, namely (1) Controvism, that is, children can construct the recitation of the Koran, coupling the letters hijaiyah into sentences (verses), (2) inquiry, namely children discovering the reading law in the Qur'an , finding similar letters in their pronunciation, (3) questioning, that is, children are able to ask questions about how to understand correctly reciting the letters of the Koran, (4) Learning comunity, namely children learning together (listening to the recitation of the Koran), (5) Modeling, namely children recognize models of letters and recitation of the Koran starting from the short length of the mad, (6) refletion, namely children can correct the law of reading the Qur'an when listening to each other and finally (7) authentic assessment, namely when researchers provide questions about children it is expected to be able to answer according to their abilities.

Based on the description above, the researchers used the approach "Application of the Contextual Teaching and Learning Approach (CTL) to Improve the Reading Ability of Alqurans in the 4th Grade Students of Slipi 15 SDN Morning". So that this research is important to answer and solve problems as described above and is expected to be able to help improve Alquran reading skills in Grade IV students at Slipi 15 Elementary School Morning.

From the background above the research problems can be formulated as follows; 1) What is the process of improving Alquran reading skills through the CTL (Contextual Teaching and Learning) approach in fourth grade students at SDN Slipi 15 Pagi West Jakarta ?; 2) What are the results of the Alquran reading ability with the CTL (Contextual Teaching and Learning) approach for SDN Slipi 15 Pagi West Jakarta students?

The objectives to be achieved in this study are 1) Describe the learning process in improving Alquran reading skills of Grade IV children at SDN Slipi 15 Pagi Jakarta through a contextual approach; 2) Knowing the improvement of children's Alquran reading through a contextual approach.

\section{Methods}

This study uses research design (action research). Kemmis \& Mc Taggart's action research includes four stages, namely (1) planning, (2) action, (3) observation, (4) reflection (reflection).

In the Kemmis \& Taggart model actions (acting) and observation (observing) are used as one unit because they assume that the two components are two activities that cannot be separated.

Data collection techniques used in this study are field notes, interviews, observations and instrument sheets. Field notes are used to obtain the objectives studied, namely about children's social skills.

The field notes are made in complete notes after the school ends so that it can be discussed with the teacher and the principal and revised to make improvements after the researcher has arrived, this process is carried out every time he makes observations. The interviews used were structured interviews and unstructured interviews and were open interviews. Interviews were conducted with principals, teachers, parents of students, and students to obtain in-depth information about the results of improving the ability to read the Qur'an through a contextual approach.

Observation is carried out by documenting activities with photos and recording the learning process to obtain data about the activities of students and teachers during learning activities that refer to contextual approaches. The instrument sheet prepared by the researcher contains indicators that are a reference in assessing students' social skills. This instrument is filled by researchers and classroom teachers by giving a check list $(\sqrt{ })$ to each indicator according to the level of skill seen in the student. Processing data in this study uses two types of data, according to the demands of action research, namely qualitative and quantitative data.

Analysis of research data using quantitative data analysis with descriptive statistics. Quantitative data analysis is used by comparing the results obtained from the first cycle and the second cycle.

Qualitative data analysis by analyzing data from field notes and interviews during the research with steps to reduce data, display data and verify data carried out in a process.

\section{Results and Discussion}

The results of this study, the researchers measured an increase in Alquran reading ability and then compared the results of the increase between before and after the action was given. Observations were made during the implementation of the action, taking notes, using both the notes, observation sheets and monitoring instruments of the actions provided. Each study in cycle I, researchers and collaborators alike evaluate each other's activities carried out based on the action monitoring instruments, observation sheets and reflections made together.

Pre-Intervention-Cycle 1 Histogram on Alquran Reading Ability of Grade IV Students of SLIPI Elementary School 15 Morning.

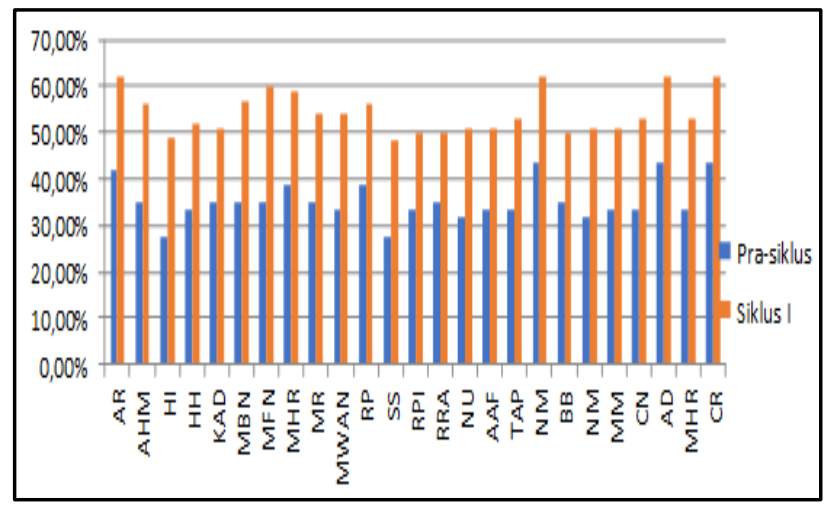

Based on the table diagram above, the average Alqur'an reading ability of students has not reached the maximum indicator according to what was planned by researchers and collaborators. Children still need to get guidance to reach the planned Qur'anic reading ability that has been planned. The cause is; a) students still cannot distinguish letters that are similar in type like Kha 'and ha, syin, and sa' b) know the names of children still have to be guided 
in the mention of lapaz letters, c) interventions from both teachers and researchers still occur frequently, d) There are still students who don't actively participate in groups. It is expected that in the second cycle the intervention can be further reduced, and the teacher gives direction and reinforcement so students want to mingle and share with other friends. Based on this, the researcher decides to proceed to the next cycle. This is because researchers and collaborators want all students to reach all student indicators. In addition researchers and collaborators want to monitor a significant percentage increase, despite an increase in Alqur'an reading skills with an average of $19.4 \%$, but the increase cannot be said to be significant according to the set percentage of $71 \%$. consistent changes will reach up to $71 \%$. Researchers and collaborators agreed to monitor the percentage increase again in the next cycle until they were able to reach targets that had been determined or agreed upon by the researchers and collaborators because they did not meet the intended and expected targets. If the percentage of students' Alqur'an reading ability continues to increase, it can be said that the percentage increase was also stated to be significant.

The following are data about the percentage of Alquran reading skills of students in cycles 1 and 2;

Pre-intervention Histograms - Cycle 1 - 2 on Alquran Reading Ability Slipi 15 SDN Students Morning

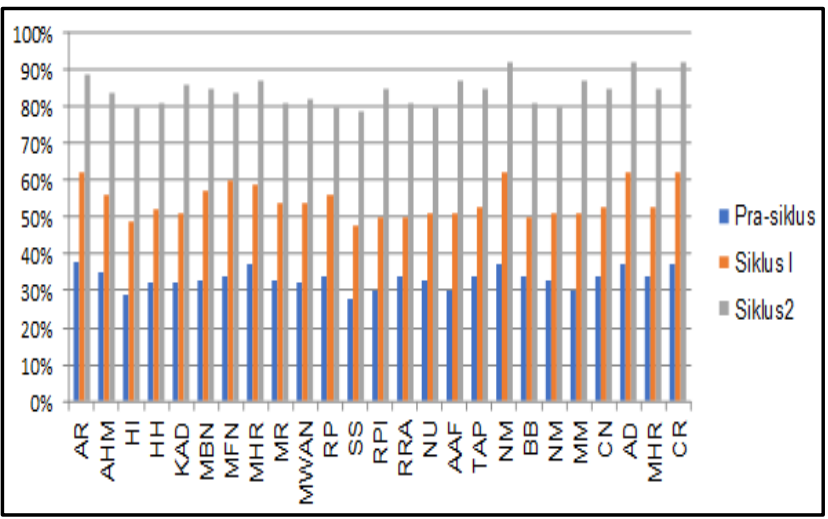

Based on the table above it can be described that the average percentage increase in cycle II for each child is 29.05\% and the development of students' Alquran reading ability has increased to $84 \%$. this means that the indicators of Alquran reading ability of students are in a developing or consistent stage. Based on this, the researcher decides not to proceed to the next cycle. In addition, researchers and collaborators have monitored the percentage increase that occurs in each cycle can be said to be significant. For this reason, researchers and collaborators agreed to stop in cycle II. As targeted in the first cycle, if the students' Alqur'an reading ability continues to increase, then the percentage increase is stated as significant. Based on this, the percentage increase can be said to be significant.

Based on the diagram on the previous page it can be seen that the ability to read Alqur'an students in each respondent changes. The increase in each respondent from the pre-cycle to the second cycle experienced an increasing change. Based on the diagram above the average ability of students to read Alqur'an increased to $84 \%$, this can also be interpreted that the ability to read Alqur'an students in recognizing the letters of the Qur'an, how to read the recitation of the Qur'an, find the law of recitation, correct, reciting the Qur'an and concluding the results of student discussions.

Based on the results of data analysis in cycle 1 , the percentage increase was obtained at $19.4 \%$ and the achievement of $54 \%$ in the second cycle the percentage increase was obtained at $29.5 \%$ and the achievement of results was $84 \%$. So the percentage of the overall increase from pre-cycle to cycle II is $49.3 \%$. This means that there has been a significant increase in the ability of students to read Alquran in the pre-study until the second cycle. The following is a graph table for improving students' Alquran reading skills.

Table 1. Analysis of Student Alquran Reading Ability Improvement in Pre Cycle, Cycle I, and Cycle II

\begin{tabular}{|c|c|c|c|}
\hline Pre Cycle & Cycle I & Cycle II & Enhancement \\
\hline $34.7 \%$ & $54 \%$ & $84 \% \%$ & $49.3 \%$ \\
\hline
\end{tabular}

Analysis of the percentage increase in pre-cycle to cycle II was calculated by the formula: Percentage of Cycle II - Pre-cycle percentage $=84 \%-34.7 \%=49.3 \%$. Graph of increasing Alquran reading skills of students from pre-cycle to cycle 2 .

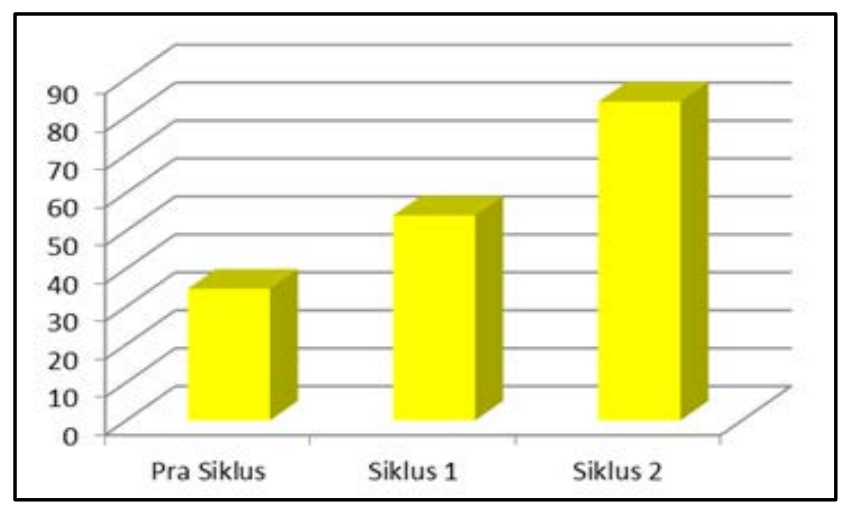

The graph states that there was an increase in the reading ability of Alquran students by $50.7 \%$ and the ability to read Alqur'an students reached $83.7 \%$ means that children experience an increase in Alqur'an reading skills of students from not appearing until very well developed. Improving the ability to read Alqur'an students refers to changes in the ability to read Alqur'an students on indicators of cooperation, grouping letters of the same Koran, adjusting the recitation of the Qur'an, determining the dignity of the Qur'an, connecting the letters of the Qur'an, answering Alqur recitations and find the law of Tajwid. The results of the observations were then carried out quantitative data analysis as a form of testing the action hypothesis using a success percentage of $71 \%$ to see the influence of the CTL approach as a learning activity on Alqur'an reading ability of SDN Slipi 15 students in the Morning.

Based on the results of the analysis of the data obtained, the overall percentage increase of $49.3 \%$ in cycle II. These results were obtained through a comparison between the percentage of Alquran reading ability of students in the pre-cycle of $34.7 \%$ with the percentage of Alquran reading ability of students in the second cycle of $84 \%$. Therefore, researchers and collaborators felt that the 
results of the percentage obtained were significant, so the researchers and team of collaborators decided to stop the study in cycle II. Based on this, the action hypothesis which states that the CTL approach with different types of media can improve Alquran reading skills at Slipi 15 SDN students in the Morning.

The results of qualitative data analysis prove that the CTL approach can improve students' Alquran reading skills. Through the CTL approach, students are more enthusiastic in learning. Through the CTL approach can develop the ability to read Alquran students by discussing together, finding and constructing letters and Alquran reading.

As for the characteristics of the CTL approach, namely, asking, constructing, learning together, discovering, reflecting and evaluating. Based on observations, through the CTL approach students can group letters of the same Qur'an, adjust the letter of Alqur'an, determine the alqur'an, read the connecting letter of the Qur'an, and find the law of tajwid. In this classroom action research, the CTL approach as a medium is used to stimulate students' Alquran reading skills.

The closing activity or review at the end of each meeting is one part of the activity that is enough to provide time for students to develop students' Alquran reading skills on each indicator. In the closing section, students can repeat the Alquran reading with short verses and can be seen from what has been done especially in the CTL approach. The teacher conducts question and answer related to the students' Alquran reading ability indicators.

Based on the description above, it can be said that the CTL approach can improve the ability to read the Alqur'an by seeing each development in the cycle, starting from the pre-cycle, the first cycle to the second cycle, this is seen when each question posed by the teacher and researcher is able to be answered by students and each characterization of the CTL approach are well implemented so that the students' reading ability of the Qur'an increases

\section{Conclude}

Based on the results of the data analysis discussion on the study entitled Improving the ability to read Al-qur'an students Through the CTL Approach can be concluded as follows; 1) The process of implementing the CTL approach can improve the ability to read the Qur'an the students of SDN Slipi 15 Morning consist of several stages, namely planning, implementation, observation and reflection, then implementation and evaluation to determine the extent of the success of the Qur'an's reading ability. students; 2) The ability to read Al-quran students at SDN Slipi 15 mornings can be improved through the CTL approach, the CTL approach can be seen from the increase in scores in the Pre-Study with a percentage of $34.7 \%$, while in the first cycle the percentage is $54 \%$. from these data it can be said that the percentage and Pre-Study to Cycle I experienced an increase in the overall indicator by $19.4 \%$. the results of the second cycle obtained a percentage of $84 \%$ so that an increase of $49.3 \%$. this shows that the percentage increase in the increase in students' Al-quran reading ability can be said to be significant because it continues to increase. Thus, it can be stated that through the CTL approach can improve the ability to read Al-qur'an grade IV students at SDN Slipi 15 Morning; 3) The advantages of CTL are being able to improve the ability to read Alqur'an (recognize the Alqur'an letters and allegations, how to read Alqur'an, find tajwid law), and be able to increase the activity of students in each lesson; 4) The lack of CTL is that it requires diverse media, lots of time and children are too free and or play alone.

\section{References}

[1] Departemen Agama RI, Al-Qur'an Dan Terjemahannya Mushaf Masjidil Aqsha. Jakarta: Al-Qur’an dan Tajwid, 2017.

[2] I. F. Laily, "Hubungan Kemampuan Membaca Pemahaman dengan Kemampuan Memahami Soal Cerita Matematika Sekolah Dasar Idah Faridah Laily,” EduMa, vol. 3, no. 1, 2014.

[3] R. A. Sani, Inovasi pembelajaran. 2013.

[4] Imam Nawawi, Ringkasan Riyadush Shalihin. Bandung: Irsyad Baitus Salam, 2006.

[5] D. H. Abul A'la al Maududi., Endin Mujahidin., "Abul A’la al Maududi, Endin Mujahidin, Didin Hafidhuddin,” J. Pendidik. Islam Ta'Dibuna, vol. 3, no. 1, pp. 1-15, 2014.

[6] Kamin Sumardi, "POTRET PENDIDIKAN KARAKTER DI PONDOK PESANTREN SALAFIAH,” J. Pendidik. Karakter, 2010.

[7] A. Musgamy, "Pengaruh Alquran dan Hadis terhadap Bahasa Arab," J. Al Hikmah, vol. XV, pp. 35-43, 2014 